\title{
Editorial: Plastic Pollution
}

\author{
François Galgani ${ }^{1 *}$, Christopher Kim Pham ${ }^{2}$ and Julia Reisser ${ }^{3}$ \\ ${ }^{1}$ French Research Institute for Exploitation of the Sea, Issy-les-Moulineaux, France, ${ }^{2}$ Marine and Environmental Sciences \\ Centre (MARE) and Institute of Marine Research (IMAR), University of the Azores, Horta, Portugal, ${ }^{3}$ The Ocean Cleanup, \\ Delft, Netherlands
}

Keywords: plastic, pollution, models, microplastics, degradation

\section{Editorial on the Research Topic}

\section{Plastic Pollution}

Our socioeconomic development models have led to an increased production of consumer goods of every type, facilitated by the petrochemical industry's ability to provide a range of cheap materials that are continuously becoming more varied. Introduced in the 1950s, plastics have continued to evolve for many purposes, and are currently used in all industrial sectors. A noteworthy application is packaging, which currently uses around $30-40 \%$ of the exponentially growing annual plastic production.

Plastics are a diverse group of synthetic materials composed of polymers (from the Greek poly $=$ many, and meros $=$ parts) predominantly derived from petrochemicals, such as petroleum and natural gas. Polyethylene, polypropylene, polystyrene, polycarbonates and polyamides, are all plastics manufactured from monomers with different chemical characteristics. They possess different properties (color, form, hardness, thickness, and degradability), which impart various

\section{OPEN ACCESS}

Edited by:

Hans Uwe Dahms,

Kaohsiung Medical University, Taiwan

Reviewed by:

Xiaoshou Liu,

Ocean University of China, China

Rodrigo Riera,

Atlantic Environmental Marine Center

(CIMA SL), Spain

${ }^{*}$ Correspondence:

François Galgani

Francois.Galgani@ifremer.fr

Specialty section:

This article was submitted to

Marine Pollution,

a section of the journal

Frontiers in Marine Science

Received: 12 July 2017 Accepted: 07 September 2017 Published: 22 September 2017

Citation:

Galgani F, Pham CK and Reisser J (2017) Editorial: Plastic Pollution.

Front. Mar. Sci. 4:307.

doi: 10.3389/fmars.2017.00307 fates once discarded in the environment. Unfortunately, some of the main plastic qualities sought by industry and consumers-lightness and resistance to degradation-are also leading to their negative impacts and persistence in natural habitats.

Marine litter is any directly or indirectly manufactured item thrown or abandoned voluntarily or involuntarily into the marine environment. It is well known that plastic is the main contributor to the growing amounts of litter accumulating in the world's oceans. Nonetheless, the marine plastic pollution research field is quite new, and more information about the nature, sources, transport, distribution and environmental effects of plastics is necessary for a better understanding of their biogeochemical cycles. Various studies have reported the existence of small plastic particles in pelagic and benthic environments that are often invisible to the naked eye. They are commonly referred to as "microplastics" $(<5 \mathrm{~mm})$ and can either be microparticles already manufactured in such small sizes or, more commonly, result from the fragmentation of larger plastic objects. The environmental implications of their presence at sea are still largely unknown.

Identifying sources and sinks of marine plastics can be difficult because pollution sources on land and at sea are often unknown and plastic particle transport and aging processes are highly dynamic and complex. Nonetheless, recent research suggest major sources are coastlines, rivers (Lebreton et al., 2017), and maritime (e.g., fishing) activities, with the presence of plastic accumulation zones being present in seafloor environments (Pham et al., 2014), beaches (Lavers and Bond, 2017), and surface waters of subtropical (Eriksen et al., 2014), Mediterranean (Cozar et al., 2015) and Arctic waters (Cozar et al., 2017). Over the past 15 years, plastic impacts in the seas have increased (Galgani, 2014), and the number of marine species known to be affected by this contaminant has gone from 247 to 680 (Gall and Thompson, 2015). A substantial portion of these impacts involves entanglement in fishing equipment and ingestion of debris, and occurs mainly in developing regions. The interaction of litter with marine organisms has been used as an approach to better map some of the risks (Wilcox et al., 2015; Darmon et al., 2017). The alteration of ecosystems caused by the transport of species over long distances also represents a major problem. 
Although there is mounting evidence that plastic pollution act as an important stressor for many marine organisms, we do not know how this is affecting the overall functioning of marine ecosystems and the services they provide. This research topic contributes to a better understanding of this type of marine contamination by presenting articles reporting observations and transport models of debris in the Adriatic Sea, Western Australian waters, Great Lakes, North West European seas, and Aegean Sea. There are also studies describing findings from (1) a statistical model that predicts areas of plastic accumulation in

\section{REFERENCES}

Cozar, A., Martí, E., Duarte, C. M., García-de-Lomas, J., van Sebille, E., Ballatore, T. J., et al., (2017). The Arctic Ocean as a dead end for floating plastics in the North Atlantic branch of the Thermohaline Circulation. Sci. Adv. 3:e1600582. doi: $10.1126 /$ sciadv. 1600582

Cozar, A., Sanz-Martín, M., Martí E., González-Gordillo, J. I., Bárbara U., Gálvez, J. A., et al. (2015). Plastic Accumulation in the Mediterranean Sea. PLoS ONE. 10:e121762 doi: 10.1371/journal.pone.01 21762

Darmon, G., Miaud, C., Claro, F., Doremus, G., and Galgani, F., (2017). Risk assessment reveals high exposure of sea turtles to marine debris in French Mediterranean and metropolitan Atlantic waters. Deep Sea Res. II Top. Stud. Oceanogr. 41, 319-328. doi: 10.1016/j.dsr2.2016. 07.005

Eriksen, M., Lebreton, L. M., Carson, H. S., Thiel, M., Moore, C., Borerro, J. C., et al. (2014). Plastic pollution in the world's oceans: more than 5 trillion plastic pieces weighing over 250,000 tons afloat at sea. PLOS ONE 9:e111913. doi: 10.1371/journal.pone.0111913

Galgani, F. (2014). "Pollution by marine debris," in Sea and Oceans, Book 3, The Land-Sea Interactions, ISTE Edition, eds A. Monaco and P. Prouzet (HERMES Penton Publishing Ltd.), 195-236.

Gall, S. C., and Thompson, R. C. (2015). The impact of debris on marine life. Mar. Pollut. Bull. 92, 170-179. doi: 10.1016/j.marpolbul.2014.12.041 the Mediterranean, (2) a 6 months experiment that simulates the generation of microplastics from the fragmentation of Polyethylene films on beaches and at sea, (3) a review of transport models for marine plastics, and (4) models predicting the overlap between fin whales and plastic debris in a marine protected area.

\section{AUTHOR CONTRIBUTIONS}

All authors listed have made a substantial, direct and intellectual contribution to the work, and approved it for publication.

Lavers, J. L., and Bond, A. L. (2017). Exceptional and rapid accumulation of anthropogenic debris on one of the world's most remote and pristine islands. Proc. Natl. Acad. Sci U.S.A. 114, 6052-6055. doi: 10.1073/pnas.1619818114

Lebreton, L., van der Zwet, J., Damsteeg, J., Slat, B., Andrady, A., and Reisser, J. (2017). River plastic emissions to the World's Oceans. Nat. Commun. 8:15611. doi: 10.1038/ncomms15611

Pham, C. K., Ramirez-Llodra, E., Alt, C. H. S., Amaro, T., Bergmann, M., Canals, M., et al. (2014). Marine litter distribution and density in European Seas, from the shelves to deep basins. PLoS ONE 9:e95839. doi: 10.1371/journal.pone.0095839

Wilcox, C., Van Sebille, E., and Hardesty, B. D. (2015). Plastic pollution to seabirds is global, pervasive, and increasing. Proc. Natl. Acad. Sci U.S.A. 112, 11899-11904. doi: 10.1073/pnas.1502108112

Conflict of Interest Statement: The authors declare that the research was conducted in the absence of any commercial or financial relationships that could be construed as a potential conflict of interest.

Copyright (c) 2017 Galgani, Pham and Reisser. This is an open-access article distributed under the terms of the Creative Commons Attribution License (CC BY). The use, distribution or reproduction in other forums is permitted, provided the original author(s) or licensor are credited and that the original publication in this journal is cited, in accordance with accepted academic practice. No use, distribution or reproduction is permitted which does not comply with these terms. 